\title{
Co-selection of antibiotic and heavy metal resistance in freshwater bacteria
}

\author{
Andrea DI CESARE, Ester M. ECKERT, Gianluca CORNO* \\ Microbial Ecology Group, National Research Council, Institute of Ecosystem Study, Largo Tonolli 50, 28922 Verbania Pallanza, Italy \\ *Corresponding author: g.corno@ise.cnr.it
}

\begin{abstract}
Antibiotic resistant bacteria are found in most environments, especially in highly anthropized waters. A direct correlation between human activities (e.g. pollution) and spread and persistence of antibiotic resistant bacteria (ARB) and resistance genes (ARGs) within the resident bacterial communities appears more and more obvious. Furthermore, the threat posed for human health by the presence of ARB and ARGs in these environments is enhanced by the risk of horizontal gene transfer of resistance genes to human pathogens. Although the knowledge on the spread of antibiotic resistances in waters is increasing, the understanding of the driving factors determining the selection for antibiotic resistance in the environment is still scarce. Antibiotic pollution is generally coupled with contamination by heavy metals (HMs) and other chemicals, which can also promote the development of resistance mechanisms, often through co-selecting for multiple resistances. The co-selection of heavy metal resistance genes and ARGs in waters, sediments, and soils, increases the complexity of the ecological role of ARGs, and reduces the effectiveness of control actions. In this mini-review we present the state-of-the-art of the research on antibiotic-and HM-resistance and their connection in the environment, with a focus on HM pollution and aquatic environments. We review the spread and the persistence of HMs and/or ARB, and how it influences their respective gene co-selection. In the last chapter, we propose Lake Orta, a system characterized by an intensive HM pollution followed by a successful restoration of the chemistry of the water column, as a study-site to evaluate the spread and selection of HMs and antibiotic resistances in heavily disturbed environments.
\end{abstract}

Key words: Co-selection; antibiotic resistance; heavy metal; anthropization; Lake Orta.

Received: February 2015. Accepted: October 2015.

\section{INTRODUCTION}

The increasing persistence of antibiotic resistant bacterial pathogens is resulting in a worldwide increment of infections and deaths (Levy and Marshall, 2004; Palmer and Kishony, 2013). The loss of therapeutic efficiency of existing antibiotics, the constant decrease in the design and production of new antibiotics, and the limited success of the measures applied to reduce the spread of antibiotic resistance (AR) highlight the need for a reconsideration of our approach to the problem (World Health Organization, 2014). It is thus necessary to deepen our knowledge on the relationship between antibiotics and AR in clinical and natural environments, since the reduced therapeutic effect of antibiotics can be correlated to the persistence of AR in human affected areas (Aminov, 2010). Human activities are responsible for a substantial release of antibiotics and of antibiotic resistant bacteria (ARB) into the environment (especially into waters), which my act as long-term reservoir of resistances (Di Cesare et al., 2015). It seems though that the direct release of ARB has a bigger impact on the occurrence of ARB in the environment compared to the contamination with antibiotics (Kümmerer, 2009).

On a genetic level, AR is due to the presence of antibiotic resistance genes (ARGs) in chromosomes and/or in mobile elements (MGE, e.g., transposons and plasmids). ARGs can be spatially or functionally associated with others genetic elements, which can cause a positive co-selection of ARGs, due to a primary selection of the associated genes (Alonso et al., 2001). Heavy metal resistance genes (HMRGs) are a well-known example of such ARG selection systems (summarized by Baker-Austin et al., 2006), since they can indirectly support the maintenance of AR in the environment in the presence of heavy metals (HMs, Icgen and Yilmaz, 2014). Such HMs are released into the environment by industry, farming and other human activities (Zubero et al., 2010; Wang and Zang, 2014; Yang et al., 2014). The selective pressure exerted by this pollution allows HM resistant bacteria (HMRB) to survive and to preserve their genetic heritage comprising ARGs.

In this review, we focus on AR in aquatic environments and on the role of HM pollution and HM resistance on the spread of AR in human impacted ecosystems. Finally we suggest, that the sediments of lakes which used to be affected by strong HM pollution and were later restored, such as Lake Orta (Northwestern Italy), could provide a historical database of heavy metal and antibiotic resistance genes. This allows to compare gene occurrence in pristine, polluted, and restored habitats, in order to gain insight into the relation between ARB and HM pollution. 


\section{ANTIBIOTIC RESISTANCE: MECHANISMS, SPREAD AND RELATIONS BETWEEN CLINICAL AND ENVIRONMENTAL SETTINGS}

The misuse and the massive use of antibiotics in human and veterinary medicine, as well as in agriculture, in the last century resulted in a constant release of antibiotics into the environment and especially into surface and ground waters of urbanized areas. In such contaminated environments antibiotics have been found in non-negligible amounts in rivers, lakes, coastal seas (reviewed by Gothwal and Shashidhar, 2014) and recently even in tap water in Spain (Valcarcel et al., 2011) and China (Huang et al., 2015).

Bacteria have developed a number of different mechanisms in order to cope with antibiotics, on a genetic (summarized by Brooks and Brooks, 2014) as well as on a phenotypic level (e.g. aggregation, Corno et al., 2014; biofilm formation, Costerton et al., 1999). Nevertheless antibiotics, even in sub- inhibitory dose, have a direct impact on the fitness and thus on the ecological success of single bacterial strains (Hall and Corno, 2014) and on the bacterial community composition (Kümmerer, 2009).

Genetic adaptation allows bacteria to acquire resistance against a specific antibiotic by i) alteration of the target of the antibiotic compounds (e.g., mutations on target sites of the antibiotics); ii) their inactivation or enzymatic alteration (for example $\beta$-lactamases); or iii) their excretion (e.g., through the activation of efflux pumps, Brooks and Brooks, 2014).

Horizontal gene transfer (HGT), meaning the transfer of genes between different organisms, plays a major role in the acquisition of AR by bacteria (Koonin, 2001). HGT can occur by three well studied mechanisms; transduction (transferring of DNA among bacteria mediated by bacterial viruses), transformation (changing of the bacterial genotype by capture of exogenous DNA), or conjugation (exchanging conjugative plasmids between physically connected bacteria). The latter requires conjugative plasmids and it is commonly observed in nature, even between organisms that are distantly related (Tazzyman and Bonhoeffer, 2014). Conjugative plasmids and/or transposons harbor not only constitutive genetic traits (responsible for their replication, spread, and maintenance) but also a variety of genes that are useful to survive under enhanced ecological pressure (Di Cesare et al., 2014; Hong et al., 2014; Norman et al., 2009 Turner et al., 2002). More recently additional mechanisms of HGT have been proposed (summarized in Popa and Dagan, 2011), suggesting that we might even underestimate the rate of gene transfer.

ARGs are an important part of the accessory gene pool of bacteria, which are necessary to allow the persistence of a specific bacterial strain in the presence of antibiotics. Therefore the finding of ARB and/or ARGs in human affected environments, where pollution of different origin (e.g., antibiotics, heavy metals, and other chemicals) is generally affecting the bacterial communities, is extensively reported (Bengtsson-Palme et al., 2014; Laht et al., 2014; Sidrach-Cardona et al., 2014; Di Cesare et al., 2015). A direct correlation between the overall abundance of ARGs in the resident bacetrial community and the presence of heavy metals, such as (copper) $\mathrm{Cu}$, (zinc) $\mathrm{Zn}$, and (arsenic) As has been reported in agricultural soils in China, where the correlation between ARGs and corresponding antibiotics resulted much weaker (Ji et al., 2012). In freshwater, a strong relationship between the source of pollution and the quantitative and spatial distribution of ARGs has been shown (Czekalski et al., 2014). Moreover many reports hint to a non-negligible amount of ARGs even in areas that are not directly impacted, such as permafrost and caves (D'Costa et al., 2011; Bhullar et al., 2012; Segawa et al., 2013).

The concomitant massive use of different antibiotics (or antimicrobial-like molecules) promotes the co-evolution of specific ARB that share the same environment and the same stress factors, with a high possibility for the development of multi drug resistant bacterial strains (MDRs), characterized by resistance against several antibiotics (Antunes et al., 2011; Khan et al., 2012; Vignaroli et al., 2012). MDRs are frequent among human and animal pathogens like Staphylococcus aureus, Enterococcus faecium, and others (e.g. Nordmann et al., 2007), and are often the result of a general misuse of antibiotics in medical and veterinary care (Chen et al., 2014). Pathogenic MDRs are thus common in human affected ecosystems where they represent one of the main threats to global public health, as stated by the World Health Organization (2014).

Nonetheless, the crucial importance of the environment (particularly waters and sediments), and of natural non-pathogenic bacteria as a long-term reservoir of ARGs becomes more and more evident (Martinez, 2008; Taylor et al., 2011). The correct management of the use of antibiotics and of the spread of resistances in the environment by national and regional health authorities requires deeper knowledge and refined management models (Holdren and Lander, 2014).

\section{HEAVY METAL POLLUTION AND RESISTANCE}

HMs constitute a serious threat to natural communities and ecosystems, because of their toxicity to most organisms (Martins et al., 2014). High concentrations of HMs are always toxic: while higher organisms cannot survive heavy contaminations, bacteria were able to evolve different resistance mechanisms, and thus persist in contaminated environments (Martins et al., 2014). Many HMs like $\mathrm{Cu}, \mathrm{Zn}$, cobalt (Co), nickel (Ni), chromium (Cr), lead $(\mathrm{Pb})$, cadmium $(\mathrm{Cd})$, mercury $(\mathrm{Hg})$, silver $(\mathrm{Ag})$, and gold $\mathrm{Au})$ are physiologically necessary for bacterial life, as they are involved in a number of cellular functions (Seiler and Berendonk, 2012) but, depending on their concentra- 
tion, they can have a toxic effect on the organism. On the other hand, metals such as antimony ( $\mathrm{Sb}$ ) and uranium (U) are strongly toxic compounds for every life form (Seiler and Berendonk, 2012).

HMs are commonly released into the environment over manifold human activities. An increasing content of different HMs on plant leaves (used as indicator of HM pollution in the atmosphere) was reported in Spain between 1941 and 2012, which suggests urbanization as a driving factor for HM pollution in the environment (Rodríguez Martín et al., 2015). A direct correlation between the human impact and HM pollution has also been shown in the sediments of a drinking water reservoir in China (Wang et al., 2015): in this recent study, the highest concentration of several HMs were detected in the layers corresponding to the beginning of the industrial age while the highest concentration of lead $(\mathrm{Pb})$ corresponded to the increase in vehicular traffic. Moreover, HMs that are used in agriculture are directly released through water run offs and can have a widespread impact on natural water bodies. $\mathrm{Cu}$ and $\mathrm{Zn}$ are commonly supplemented to livestock-feed as growth promoter (Fard et al., 2011); $\mathrm{Fe}, \mathrm{Co}$ and manganese (Mn), $\mathrm{Cu}$, and $\mathrm{Zn}$ are used as nutritional additives in livestock and fish-feed (Seiler and Berendonk, 2012). Oil processing is an additional important cause of HMs release into the environment: traces of HMs are present in crude oil and in derivatives of petroleum (Máthé et al., 2012). In the last decades, steel production and a number of productions of metal based devices caused non-negligible releases of HMs into the environment including lakes, rivers and their sediments (Scerbo et al., 1999).

Resistances to HMs have evolved in bacteria through a number of accessory genes which are part of a complex genetic repertoire (Fard et al., 2011; Gómez-Sanz et al., 2013). These resistances include three known mechanisms against HM toxicity: i) complexation or sequestering of the $\mathrm{HM}$; ii) detoxification by sequestering of intra-cellular metal ions; and iii) excretion of the HM (reviewed by Seiler and Berendonk, 2012). HMRB were recovered from different matrixes, including water, sediment, and food (Akimbowale et al., 2007; Matyar et al., 2008). The frequency of HMRB for each HM is different and the factor that most contribute to the composition of a HM-resistome is the environment of origin (e.g. water, sediments, or animal tissues) of the bacterial community (Matyar et al., 2008). HM resistance is not only spread within environmental bacterial populations, but it has also been detected in bacterial strains from clinical environments and in human pathogens. For example, Xu and coworkers (2014) demonstrated that around half of the 71 Listeria monocytogenes they isolated from food were resistant to $\mathrm{Cd}$. A number of other studies found HM resistances related to different human pathogens: e.g. Fard and co-workers (2011) isolated 192 enterococcal strains from pigs which were all intermediately resistant to $\mathrm{Cu}$ (most of them through the efflux pump tcrB; Hasman and Aarestrup, 2005), and approximatively $40 \%$ were also resistant to $\mathrm{Zn}$ at different levels. In another case, Vibrio cholerae and Vibrio pahraemoliticus isolated from water and shrimps were resistant to $\mathrm{Cu}, \mathrm{Cd}, \mathrm{Hg}, \mathrm{Zn}$, and $\mathrm{Pb}$ (Song et al., 2013). Staphylococcus aureus strains from humans were found resistant to $\mathrm{Cu}$ and $\mathrm{Cd}$ (Gómez-Sanz et al., 2013), and a clinical Pseudomonas aeruginosa isolate was resistant to $\mathrm{Cu}$ and Zn (Ramírez-Díaz et al., 2011).

Differently than ABR, HMR is not a direct threat for human health, and HM resistant bacteria can be used for environmental restoration and in a number of industrial processes (Máthé et al., 2012).

However HMR can become a risk for human health if HMRGs and ARGs are connected in the same bacterium, favoring the spread of AR.

\section{CO-SELECTION OF ANTIBIOTIC AND HEAVY METAL RESISTANCE}

Co-selection is here defined as the concomitant evolutionary selection of two or more genes, even when exposed to a single selective stressor. The co-selection with HMRGs has been postulated to be a major path for the spread and persistence of ARs in different environments (Wright et al., 2006; Wardwell et al., 2009; Rosewarne et al., 2010). Antibiotic and HM resistance can be associated by sharing of function (HMR and AR expressed by the same gene, commonly indicated as cross-resistance), by co-regulation of their gene expression and by the co-localization of resistance genes (HM and AR genes physically located on the same mobile element).

Cross-resistance is usually implemented by efflux pumps, which eject the antibiotics and HMs from the bacterial cell. Mata and co-authors (2000), for example, reported a multidrug efflux pump which also exudates heavy metals $(m d r L)$ in Listeria monocytogenes.

In the case of co-regulation the gene expression of HMRGs and ARGs are influenced by the same factor: for example, during the characterization of the efflux pump CzcCBA (responsible for the resistance to $\mathrm{Zn}$ and $\mathrm{Cd}$ ) in Pseudomonas aeruginosa, Perron and co-authors (2004) found that its expression was regulated by two genes (CzcS and CzcR), which also controlled the expression of the OprD porin, responsible for the resistance against the carbapenems (class of $\beta$-lactam antibiotics).

The co-localization of HM and AR genes and MGEs is responsible for the co-selection of ARGs as a consequence of HM pollution. This means that ARGs can maintained in the environment by co-selection with HMRGs in polluted areas, since the level of HM pollution is several orders of magnitude greater than the pollution with antibiotics (Stepanauskas et al., 2005). Indeed if these genes are linked to MGEs the lateral transfer of the whole gene cluster to other bacteria is possible (Fig. 1; 
Pasquaroli et al., 2014; Silveira et al., 2014). Additionally, so called integrons can be present in MGEs. Integrons are genetically non-mobile elements, involved in the integration of gene cassettes and responsible for the transmission of e.g. ARGs (Ravi et al., 2014). A positive correlation between the abundance of the class I integrons and the concentrations of $\mathrm{Cu}, \mathrm{Zn}, \mathrm{Hg}$, and $\mathrm{Pb}$ has been shown in freshwater sediment samples (Rosewarne et al., 2010) and the frequency of class I integrons has been postulated as a good proxy for anthropogenic pollution in the environment (Gillings et al., 2015). Moreover, the co-presence of ARG, HMRGs and transposition modules (Tn-402 like) in class I integrons has been found in a variety of bacterial isolates; these findings suggest a possible role of class I integrons in the lateral transfer and in the co-selection of ARGs and HMRGs in environmental microbial communities (Rosewarne et al., 2010). Although the factors that influence the spread of integrons remain largely unknown, it can be speculated that the presence of HMs in aquatic environments can lead to the persistence of mobile elements through co-selection (Rosewarne et al., 2010). Furthermore, the potential co-transfer, leading to a concomitant spread of ARGs and HMRGs, can be hypothesized from the results of a number of studies (Firth et al., 2000; Schlüter et al., 2007; Stepanauskas et al., 2006; Summers, 2006). These early observations were strengthen by a recent study showing the concomitant presence of ARGs and HMRGs encoded on a conjugative plasmid of a pathogenic Escherichia coli strain isolated from a municipal sewage treatment plant (Wibberg et al., 2013). Overall, these findings suggest a positive correlation between HMs and the persistence of AR in human affected waters, with the risk of the spread of AR back to human pathogens.

\section{LAKE ORTA, AN IDEAL CASE STUDY?}

Lake Orta is a large subalpine lake in Northwestern Italy, and it is characterized by the impact of an intensive industrial pollution, from which it fully recovered to oligotrophic conditions (Baudo et al., 2001). The pollution of the lake started in 1927 due to the discharge of wastewaters from a textile company, which were rich in $\mathrm{Cu}$ and ammonium sulphate. Thereafter other heavy metals $(\mathrm{Cr}$, $\mathrm{Ni}, \mathrm{Zn}$ ) reached the lake from several plating factories and the lake became rapidly inhospitable (Calderoni and Tartari, 2001). In 1989-1990 the Institute of Ecosystem Study of the National Research Council of Italy (CNR-ISE) realized a large restoration process termed "Liming", which is based on the release of calcium carbonate to reduce the acidity (due to the oxidation of the Ammonium to Nitrate) of the lake. This intervention promoted the rapid and massive reduction of the concentration of $\mathrm{Cu}$ and other $\mathrm{HMs}$ in the water column, by recovering the original alkalinity regime and processes of nitrification (Calderoni and Tar- tari, 2001). Heavy metals are now only detectable in the sediments (Fig. 2) with higher concentrations detected within the first $20 \mathrm{~cm}$ (Baudo and Beltrami, 2001). The microbiology of the lake remains a black-box, particularly compared to well characterized microbial communities of other alpine (Callieri et al., 2006) and subalpine lakes in the area (Callieri et al., 2007, 2012; Bertoni et al., 2010).

Although the lake is nowadays close to pristine conditions (Bonacina, 2001; Calderoni and Tartari, 2001), the long period of exposure to HMs have likely induced the development of resistant bacteria within the resident microbial community (Fard et al., 2011).

Currently, there is very little impact of human activities on the lake (no direct input of treated wastewaters, little resident population on the shores, very reduced drainage, basin mostly mountainous, with little agricultural production and animal farming) suggesting a potentially limited spread of antibiotic resistances of human origin (Baudo, 2002). Thus, the sediment of Lake Orta is an interesting site for the study of the potential long-term co-selection of ARGs mediated by HMRGs.

Thanks to the stratification of sediment layers, sediment cores provide a unique archive of a lake's chemistry and biology (Guilizzoni et al., 2001). The potential of

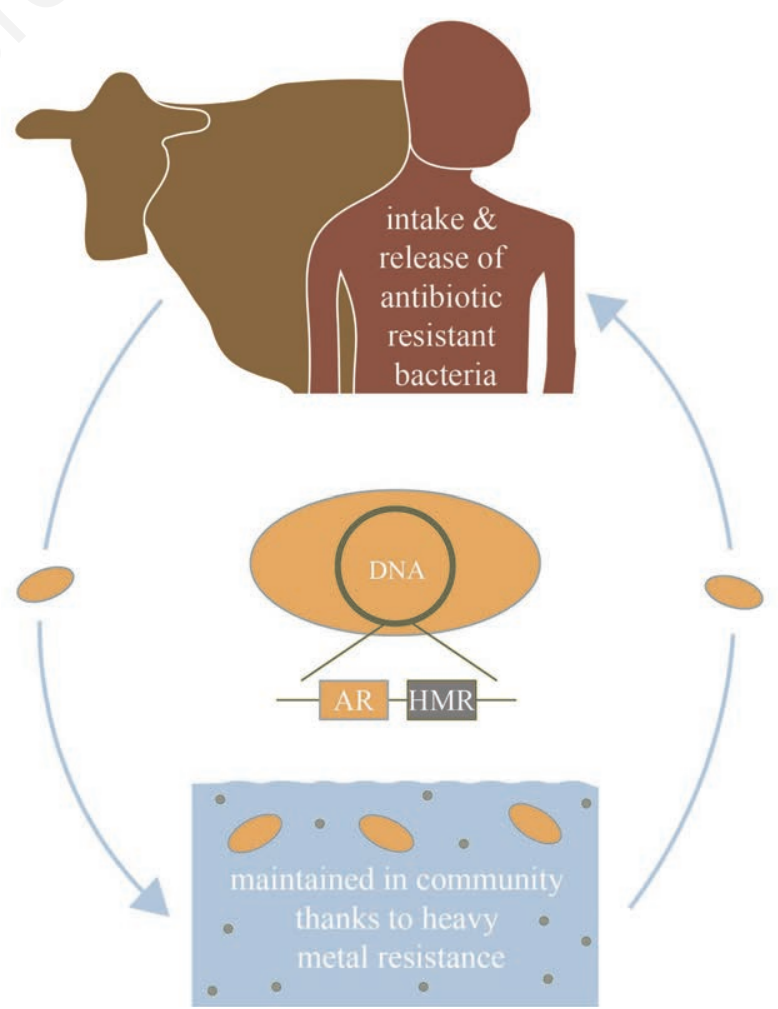

Fig. 1. Graphical depiction of the co-selection mechanism: ARGs and HMRGs located on the same genetic element are released in human affected areas and maintained in HM polluted waters, where they pose a serious threaten for human health. 
such cores is commonly used in Cladoceran biology (Jeppesen et al., 2001), where they allow to reconstruct past situations but also to experimentally test eco-evolutionary hypothesis (Dietl and Flessa, 2011). For example, it has been experimentally shown that daphnids recovered from the polluted sediment layers of Lake Orta perform better under $\mathrm{Cu}$-stress then without $\mathrm{Cu}$, indicating an evolutionary adaptation to the pollution (Piscia et al., 2014).

Such approaches are less commonly used for microbiological purposes (Li et al., 2006; Shivaji et al., 2011). Refined molecular methods allowed the analysis of the genetic potential of the bacterial community over the course of time using sediment cores (Osborn et al., 1997; D'Costa et al., 2011). Since the sediment of Lake Orta is characterized by a gradient of concentration of HMs (Fig. 2), and each layer correspond to a specific era, it provides a potential temporal archive of the effects of pollution. The bacterial DNA extracted from the different sediment layers can be considered as a proxy of the ARs and HMRs characterizing the differ-

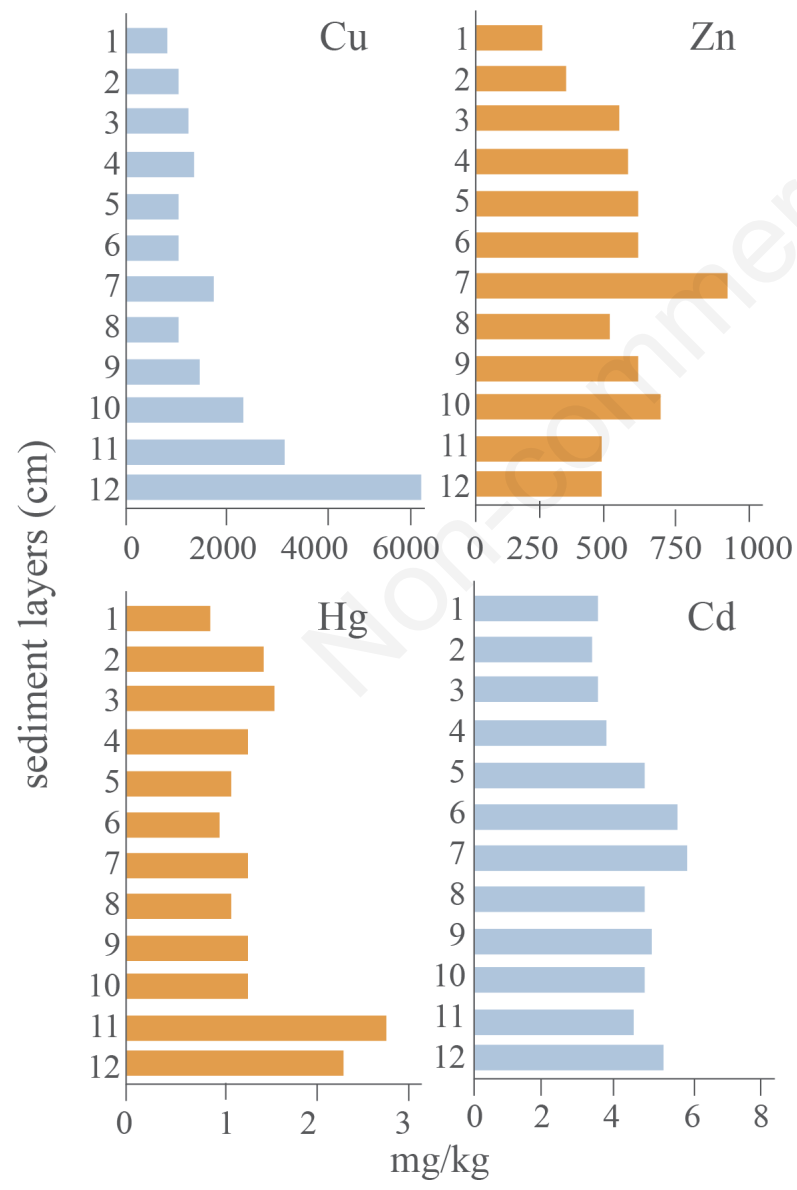

Fig. 2. Copper $(\mathrm{Cu})$, Zinc ( $\mathrm{Zn})$, Mercury $(\mathrm{Hg})$ and Cadmium (Cd) concentrations in the first $12 \mathrm{~cm}$ of sediments at the site of Omegna in Lake Orta, at the end of the 1990s (Graphs modified from Baudo and Beltrami, 2001). ent ages and the different states of pollution of Lake Orta. Even considering the effects of DNA degradation in time, of long-term adapatations, and of evolutionary forces on a community level, the profile of resistance of the microbial community provides evidence for the situations before (historical, without the exposition to HMs, depth sediments), during (pollution, sampling the sediment at depths corresponding to the highest concentrations of HMs and associated to the pollution decades), and after (restoration and contemporary, corresponding to the most superficial sediment layers and to the water-sediment interface) the pollution (Fig. 3). Furthermore, in order to evaluate how the long-term exposure to HM pollution could influence the overall composition of the microbial community nearby non-polluted lakes (e.g., oligotrophic Lake Mergozzo) could be used as clean reference.

Applying approaches such as metagenomics, would allow to gain insight into various fundamental questions, such as: (1) How does the occurrence of HMRGs and ARGs in the sediment differ with and without pollution? (2) To which extend does HM pollution stimulate HMR? (3) Is it possible to assess a connection between ARGs and HMRGs in such an environment? (4) Did the reduction in pollution also reduce the frequency of resistant genes? (5) Does the current unpolluted situation resemble the pre-pollution gene pool or is there a "genetic memory" of the pollution? Or in other words; to what extent was the community resilient (Baudo, 2002)?

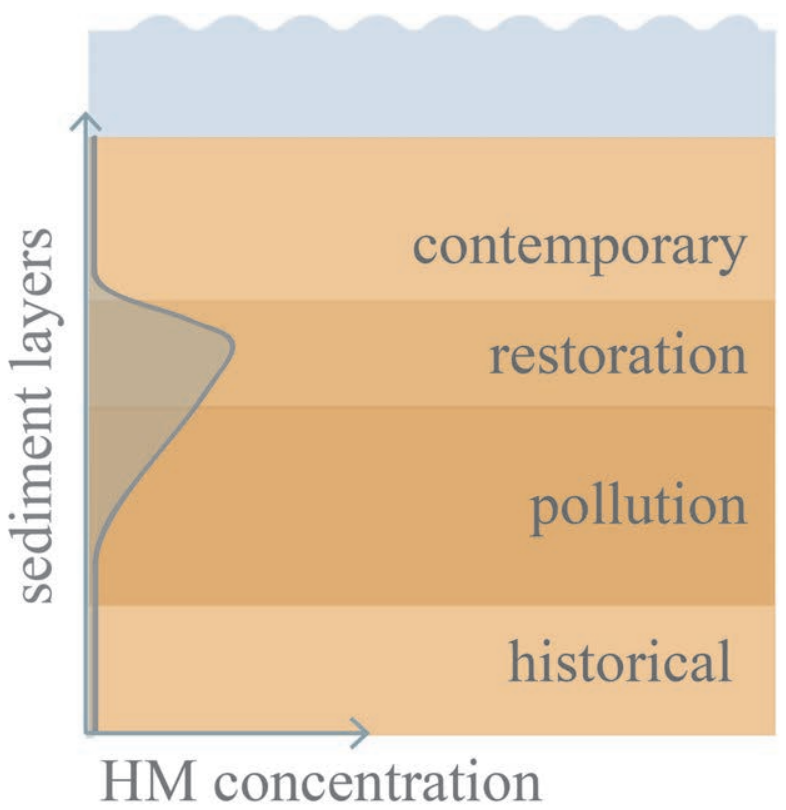

Fig. 3. Theoretical reconstruction of the different sediment layers of a lake that faced HM pollution and later restoration (e.g. Lake Orta). The highest amount of HM in the sediments are expected during the restoration process, when the HM dissolved in the water column precipitate as consequence of the restoring actions. 


\section{CONCLUSIONS}

Answering the aforementioned questions will provide great insights into the establishment and the co-selection of AR in the case of a HM pollution. Moreover, it could elucidate the long term consequences of such a pollution on the environmental gene pool.

Thus, HM polluted lakes and similar environments characterized by a comparable history of HM pollution and restoration around the world (Andersen and Pempkowiak, 1999; Hutchinson and Havas, 1985), are natural experimental systems where basic ecological hypotheses on the interactions between organisms in artificially modified environments can be validated.

The involvement of HMRGs in the accessory genetic repertoire utilized by a number of bacteria to survive within and outside their natural environment have been shown. While the mechanisms of co-selection of HMRGs and ARGs are well studied and ample research on laboratory and clinical strains has been carried out, fundamental research is still needed to assess its importance in the environment, especially on the level of community and population ecology. Using sediment cores for this purpose might not deliver a quantitative answer to the problem, it, however, allows to evaluate which HMRGs might be important selectors for ARGs, which nowadays are one of the main threads to human and animal health.

\section{ACKNOWLEDGMENTS}

We would like to thank the editors of the Journal of Limnology for the invitation to write this mini-review. We are also grateful to Alcide Calderoni, Monica Beltrami, Cristiana Callieri, and Michela Rogora for their valuable comments on Lake Orta history and restoration process. We thank Prof. Alex Hall for the proofreading of the manuscript. This work is supported by the International Commission for the Protection of Italian-Swiss Waters (CIPAIS).

\section{REFERENCES}

Akimbowale OL, Peng H, Barton MD, 2007. Diversity of tetracycline resistance genes in bacteria from acquaculture sources in Australia. J. Appl. Microbiol. 103:2016-2025.

Alonso A, Sánchez P, Martínez JL, 2001. Environmental selection of antibiotic resistance genes. Environ. Microbiol. 3:1-9.

Aminov RI, 2010. A brief history of the antibiotic era: lessons learned and challenges for the future. Front. Microbiol. 1:134.

Andersen DO, Pempkowiak J, 1999. Sediment content of metals before and after lake water liming. Sci. Total Environ. 243244:107-118.

Antunes LCM, Han J, Ferreira RBR, Lolić P, Borchers CH, Finlay BB, 2011. Effect of antibiotic treatment on the intestinal metabolome. Antimicrob. Agents Chemother. 55:1494-1503.

Baker-Austin C, Wright MS, Stepanauskas R, Mc Arthur JV, 2006. Co-selection of antibiotic and metal resistance. Trends Microbiol. 1:176-182.
Baudo R, 2002. Pollution and recovery of Lake Orta (Italy): Resilience at work? Aquat. Ecosyst. Health 5:71-78.

Baudo R, Beltrami M, 2001. Chemical composition of lake Orta sediments. J. Limnol. 60:82-105.

Baudo R, Rossi D, Beltrami M, 2001. In situ toxicity testing of Lake Orta sediments. J. Limnol. 60:277-284.

Bengtsson-Palme J, Boulund F, Fick J, Kristiansson E, Larsson DGJ, 2014. Shotgun metagenomics reveals a wide array of antibiotic resistance genes and mobile elements in a polluted lake in India. Front. Microbiol. 5:648.

Bertoni R, Callieri C, Corno G, Rasconi S, Caravati E, Contesini M, 2010. Long-term trends of epilimnetic and hypolimnetic bacteria and organic carbon in a deep holo-oligomictic lake. Hydrobiologia 644:279-287.

Bhullar K, Waglechner N, Pawlowski A, Koteva K, Banks ED, Johnston MD, Barton HA, Wright GD, 2012. Antibiotic resistance is prevalent in an isolated cave microbiome. PLoS One 7:e34953.

Bonacina C, 2001. Has Lake Orta completely recovered from its heavy polluted condition? A seventy years long history. J. Limnol. 60:285-287.

Brooks BD, Brooks AE, 2014. Therapeutic strategies to combat antibiotic resistance. Adv. Drug Deliver. Rev. 78:14-27.

Calderoni A, Tartari GA, 2001. Evolution of the water chemistry of Lake Orta after liming. J. Limnol. 60:17-26.

Callieri C, Caravati E, Corno G, Bertoni R, 2012. Picocyanobacterial community structure and space-time dynamics in the subalpine Lake Maggiore (N. Italy). J. Limnol. 71:95-103.

Callieri C, Corno G, Bertoni R, 2006. Bacterial grazing by mixotrophic flagellates and Daphnia longispina: a comparison in a fishless alpine lake. Aquat. Microb. Ecol. 42:127-137.

Callieri C, Corno G, Caravati E, Galafassi S, Bottinelli M, Bertoni R, 2007. Photosynthetic characteristics and diversity of freshwater Synechococcus at two depths during different mixing conditions in a deep oligotrophic lake. J. Limnol. 66:81-89.

Chen CW, Hsu CY, Lai SM, Syu WJ, Wang TY, Lai PS, 2014. Metal nanobullets for multidrug resistant bacteria and biofilms. Adv. Drug Deliver. Rev. 78:88-104.

Corno G, Coci M, Giardina M, Plechuk S, Campanile F, Stefani S, 2014. Antibiotics promote aggregation within aquatic bacterial communities. Front. Microbiol. 5:297.

Costerton JW, Stewart PS, Greenberg EP, 1999. Bacterial biofilms: a common cause of persistent infections. Science 284:1318-1322.

Czekalski N, Gascón Díez E, Bürgmann H, 2014. Wastewater as a point source of antibiotic-resistance genes in the sediment of a freshwater lake. ISME J. 8:1381-1390.

D'Costa VM, King CE, Kalan L, Morar M, Sung WWL, Schwarz C, Froese D, Zazula G, Calmels F, Debruyne R, Golding GB, Poinar HN, Wright GD, 2011. Antibiotic resistance is ancient. Nature 477:457-461.

Di Cesare A, Pasquaroli S, Vignaroli C, Paroncini P, Luna GM, Manso E, Biavasco F, 2014. The marine environment as a reservoir of enterococci carrying resistance and virulence genes strongly associated with clinical strains. Environ. Microbiol. Rep. 6:184-190.

Di Cesare A, Eckert E, Teruggi A, Fontaneto D, Bertoni R, Callieri C, Corno G. 2015. Constitutive presence of antibiotic resistance genes within the bacterial community of a large subalpine lake. Mol. Ecol. 24:3888-3900. 
Dietl GP, Flessa KW, 2011. Conservation paleobiology: putting the dead to work. Trends Ecol. Evol. 26:30-37.

Fard RM, Heuzenroeder MW, Barton MD, 2011. Antimicrobial and heavy metal resistance in commensal enterococci isolated from pigs. Vet. Microbiol. 148:276-282.

Firth N, Apisiridej S, Berg T, O'Rourke BA, Curnock S, Dyke KG, Skurray RA, 2000. Replication of staphylococcal multiresistance plasmids. J. Bacteriol. 182:2170-2178.

Gillings MR, Gaze WH, Pruden A, Smalla K, Tiedje JM, Zhu YG, 2015. Using the class 1 integron-integrase gene as a proxy for anthropogenic pollution. ISME J. 9:1269-1279.

Gómez-Sanz E, Kadlec K, Fessler AT, Zarazaga M, Torres C, Schwarz S, 2013. Novel erm(T)-carrying multiresistance plasmids from porcine and human isolates of methicillin-resistant Staphylococcus aureus ST398 that also harbor cadmium and copper resistance determinants. Antimicrob. Agents Chemother. 57:3275-3282.

Gothwal R, Shashidhar T, 2015. Antibiotic pollution in the environment: a review. Clean Soil Air Water 43:1863-0669.

Guilizzoni P, Lami A, Marchetto A, Appleby PG, Alvisi F, 2001. Fourteen years of palaeolimnological research of a past industrial polluted lake (L. Orta, Northern Italy): an overview. J. Limnol. 60:249-262.

Hall AR, Corno G, 2014. Tetracycline modifies competitive interactions in experimental microcosms containing bacteria isolated from freshwater. FEMS Microbiol. Ecol. 90:168-174.

Hasman H, Aarestrup FM, 2005. Relationship between copper, glycopeptide, and macrolide resistance among Enterococcus faecium strains isolated from pigs in Denmark between 1997 and 2003. Antimicrob. Agents Chemother. 49:454-456.

Holdren JP, Lander E, 2014. Report to the President on combating antibiotic resistance. In PCAST [ed.], PsCoAoSaT, Washington (USA).

Hong H, Jung J, Park W, 2014. Plasmid-encoded tetracycline efflux pump protein alters bacterial stress responses and ecological fitness of Acinetobacter oleivorans. PLoS One. 9:e107716. Icgen B, Yilmaz F, 2014. Co-occurrence of antibiotic and heavy metal resistance in Kizilirmak river isolates. Bull. Environ. Contam. Toxicol. 93:735-743.

Huang R, Ding P, Huang D, Yangemail F, 2015. Antibiotic pollution threatens public health in China. The Lancet 385(9970):773-774.

Jeppesen E, Leavitt P, De Meester L, Jensen JP, 2001. Functional ecology and palaeolimnology: using cladoceran remains to reconstruct anthropogenic impact. Trends Ecol. Evol. 16: 191-198.

Ji X, Shen Q, Liu F, Ma J, Xu G, Wang Y, Wu M, 2012. Antibiotic resistance gene abundances associated with antibiotics and heavy metals in animal manures and agricultural soils adjacent to feedlots in Shanghai, China. J. Hazard. Mater. 235:178-185.

Khan S, Tøndervik A, Sletta H, Klinkenberg G, Emanuel C, Onsøyen E, Myrvold R, Howe RA, Walsh TR, Hill KE, Thomas DW, 2012. Overcoming drug resistance with alginate oligosaccharides able to potentiate the action of selected antibiotics. Antimicrob. Agents Chemother. 56:5134-5141.

Koonin EV, Makarova KS, Aravind L 2001. Horizontal gene transfer in prokaryotes: quantification and classification. Annu. Rev. Microbiol. 55:709-742.

Kümmerer K, 2009. Antibiotics in the aquatic environment - A review - Part II. Chemosphere 75:435-441.
Laht M, Karkman A, Voolaid V, Ritz C, Tenson T, Virta M, Kisand V, 2014. Abundances of tetracycline, sulphonamide and beta-lactam antibiotic resistance genes in conventional wastewater treatment plants (WWTPs) with different waste load. PLoS ONE 9:e103705.

Levy SB, Marshall B, 2004. Antibacterial resistance worldwide: causes, challenges and responses. Nat. Med. 10:S122-S129.

Li S, Xiao X, Yin X, Wang F, 2006. Bacterial community along a historic lake sediment core of Ardley Island, west Antarctica. Extremophiles 10:461-467.

Martinez JL, 2008. Antibiotics and antibiotic resistance genes in natural environments. Science 321:365-367.

Martins VV, Zanetti MO, Pitondo-Silva A, Stehling EG, 2014. Aquatic environments polluted with antibiotics and heavy metals: a human health hazard. Environ. Sci. Pollut. Res. Int. 21:5873-5878.

Mata MT, Baquero F, Pérez-Díaz JC, 2000. A multidrug efflux transporter in Listeria monocytogenes. FEMS Microbiol. Lett. 187:185-188.

Máthé I, Benedek T, Táncsics A, Palatinszky M, Lányi S, Márialigeti K, 2012. Diversity, activity, antibiotic and heavy metal resistance of bacteria from petroleum hydrocarbon contaminated soils located in Harghita County (Romania). Int. Biodeter. Biodegr. 73:41-49.

Matyar F, Kaya A, Dinçer S, 2008. Antibacterial agents and heavy metal resistance in Gram-negative bacteria isolated from seawater, shrimp and sediment in Iskenderun Bay, Turkey. Sci. Total Environ. 407:279-285.

Morgan RPC, 2005. Soil erosion and conservation. Blackwell Publishing, Malden: 316 pp.

Nordmann P, Naas T, Fortineau N, Poirel L, 2007. Superbugs in the coming new decade; multidrug resistance and prospects for treatment of Staphylococcus aureus, Enterococcus spp. and Pseudomonas aeruginosa in 2010. Curr. Opin. Microbiol. 10:436-440.

Norman A, Hansen LH, Sørensen SJ, 2009. Conjugative plasmids: vessels of the communal gene pool. Philos. Trans. R. Soc. Lond. B. Biol. Sci. 364:2275-2289. Osborn AM, Bruce KD, Strike P, Ritchie DA, 1997. Distribution, diversity and evolution of the bacterial mercury resistance (mer) operon. FEMS Microbiol. Rev. 19:239-262.

Palmer AC, Kishony R, 2013. Understanding, predicting and manipulating the genotypic evolution of antibiotic resistance. Nat. Rev. Gen. 14:243.

Pasquaroli S, Di Cesare A, Vignaroli C, Conti G, Citterio B, Biavasco F, 2014. Erythromycin- and copper-resistant Enterococcus hirae from marine sediment and co-transfer of erm(B) and tcrB to human Enterococcus faecalis. Diagn. Microbiol. Infect. Dis. 80:26-28.

Perron K, Caille O, Rossier C, Van Delden C, Dumas JL, Kohler T, 2004. CzcR-CzcS, a two-component system involved in heavy metal and carbapenem resistance in Pseudomonas aeruginosa. J. Biol. Chem. 279:8761-8768.

Piscia R, Colombini M, Ponti B, Bettinetti R, Monticelli D, Rossi V, Manca M, 2014. Lifetime response of contemporary versus resurrected Daphnia galeata Sars (Crustacea, Cladocera) to $\mathrm{Cu}$ (II) chronic exposure. Bull. Environ. Contam. Toxicol.:1-6.

Popa O, Dagan T, 2011. Trends and barriers to lateral gene transfer in prokaryotes. Curr. Opin. Microbiol. 14:615-623. 
Ramírez-Díaz MI, Díaz-Magaña A, Meza-Carmen V, Johnstone L, Cervantes C, Rensing C, 2011. Nucleotide sequence of Pseudomonas aeruginosa conjugative plasmid pUM505 containing virulence and heavy-metal resistance genes. Plasmid 66:7-18.

Ravi A, Avershina E, Ludvigsen J, L'Abée-Lund TM, Rudi K, 2014. Integrons in the intestinal microbiota as reservoirs for transmission of antibiotic resistance genes. Pathogens $3: 238-248$.

Rodríguez Martín JA, De Arana C, Ramos-Miras JJ, Gil C, Boluda R, 2015. Impact of 70 years urban growth associated with heavy metal pollution. Environ. Pollut. 196:156-163.

Rosewarne CP, Pettigrove V, Stokes HW, Parsons YM, 2010. Class 1 integrons in benthic bacterial communities: abundance, association with Tn402-like transposition modules and evidence for coselection with heavy-metal resistance. FEMS Microbiol. Ecol. 72:35-46.

Scerbo R, Possenti L, Lampugnani L, Ristori T, Barale R, Barghigiani C, 1999. Lichen (Xanthoria parietina) biomonitoring of trace element contamination and air quality assessment in Livorno Province (Tuscany, Italy). Sci. Total Environ. 241:91-106.

Schlüter A, Szczepanowski R, Pühler A, Top EM, 2007. Genomics of IncP-1 antibiotic resistance plasmids isolated from wastewater treatment plants provides evidence for a widely accessible drug resistance gene pool. FEMS Microbiol. Rev. 31:449-477.

Segawa T, Takeuchi N, Rivera A, Yamada A, Yoshimura Y, Barcaza G, Shinbori K, Motoyama H, Kohshima S, Ushida K, 2013. Distribution of antibiotic resistance genes in glacier environments. Environ. Microbiol. Rep. 5:127-134.

Seiler C, Berendonk TU, 2012. Heavy metal driven co-selection of antibiotic resistance in soil and water bodies impacted by agriculture and aquaculture. Front. Microbiol. 3:399.

Shivaji S, Kumari K, Kishore KH, Pindi PK, Rao PS, Radha Srinivas TN, Asthana R, Ravindra R, 2011. Vertical distribution of bacteria in a lake sediment from Antarctica by culture-independent and culture-dependent approaches. Res. Microbiol. 162:191-203.

Sidrach-Cardona R, Hijosa-Valsero M, Marti E, Balcázar JL, Becares E, 2014. Prevalence of antibiotic-resistant fecal bacteria in a river impacted by both an antibiotic production plant and urban treated discharges. Sci. Total Environ. 488489:220-227.

Silveira E, Freitas AR, Antunes P, Barros M, Campos J, Coque TM, Peixe L, Novais C, 2014. Co-transfer of resistance to high concentrations of copper and first-line antibiotics among Enterococcus from different origins (humans, animals, the environment and foods) and clonal lineages. J. Antimicrob. Chemother. 69:899-906.

Song Y, Yu P, Li B, Pan Y, Zhang X, Cong J, Zhao Y, Wang H, Chen L, 2013. The mosaic accessory gene structures of the SXT/R391-like integrative and conjugative elements derived from Vibrio spp. isolated from aquatic products and environment in the Yangtze River estuary, China. BMC Microbiol. 13:214.

Stepanauskas R, Glenn TC, Jagoe CH, Tuckfield RC, Lindell $\mathrm{AH}, \mathrm{Mc}$ Arthur JV, 2005. Elevated microbial tolerance to metals and antibiotics in metal-contaminated industrial environments. Environ. Sci. Technol. 39:3671-3678.
Stepanauskas R, Glenn TC, Jagoe CH, Tuckfield RC, Lindell AH, King CJ, McArthur JV, 2006. Coselection for microbial resistance to metals and antibiotics in freshwater microcosms. Environ. Microbiol. 8:1510-1514.

Summers AO, 2006. Genetic linkage and horizontal gene transfer, the roots of the antibiotic multi-resistance problem. Anim. Biotechnol. 17:125-135.

Taylor NGH, Verner-Jeffreys DW, Baker-Austin C, 2011. Aquatic systems: maintaining, mixing and mobilising antimicrobial resistance? Trends Ecol. Evol. 26:278-284.

Tazzyman SJ, Bonhoeffer S, 2014. Why there are no essential genes on plasmids. Mol. Biol. Evol. 32: 3079-3088.

Turner SL, Bailey MJ, Lilley AK, Thomas CM, 2002. Ecological and molecular maintenance strategies of mobile genetic elements. FEMS Microbiol. Ecol. 42:177-185.

Valcarcel Y, Alonso SG, Rodriguez-Gil JL, Gil A, Catala M, 2011. Detection of pharmaceutically active compounds in the rivers and tap water of the Madrid Region (Spain) and potential ecotoxicological risk. Chemosphere 84:1336-1348.

Vignaroli C, Luna GM, Rinaldi C, Di Cesare A, Danovaro R, Biavasco F, 2012. New sequence types and multidrug resistance among pathogenic Escherichia coli isolates from coastal marine sediments. Appl. Environ. Microbiol. 78:3916-3922.

Wang X, Zang S, 2014. Distribution characteristics and ecological risk assessment of toxic heavy metals and metalloid in surface water of lakes in Daqing Heilongjiang Province, China. Ecotoxicology 23:609-617.

Wang G, A Y, Jiang H, Fuc Q, Zheng B, 2015. Modeling the source contribution of heavy metals in surficial sediment and analysis of their historical changes in the vertical sediments of a drinking water reservoir. J. Hydrol. 520:37-51.

Wardwell L, Jude B, Moody J, Olcerst A, Gyure R, Nelson R, Fekete F, 2009. Co-selection of mercury and antibiotic resistance in sphagnum core samples dating back 2000 years. Geomicrobiol. J. 26:351-360.

Wibberg D, Szczepanowski R, Eikmeyer FG, Pühler A, Schlüter $A, 2013$. The IncF plasmid pRSB225 isolated from a municipal wastewater treatment plant's on-site preflooder combining antibiotic resistance and putative virulence functions is highly related to virulence plasmids identified in pathogenic E. coli isolates. Plasmid 69:127-137.

World Health Organization, 2014.Antimicrobial resistance: global report on surveillance. World Health Organization, Geneva: 257 pp.

Wright MS, Peltier GL, Stepanauskas R, Mc Arthur JV, 2006. Bacterial tolerances to metals and antibiotics in metal-contaminated and reference streams. FEMS Microbiol. Ecol. 58:293-302.

Xu D, Li Y, Zahid MS, Yamasaki S, Shi L, Li JR, Yan H, 2014. Benzalkonium chloride and heavy-metal tolerance in Listeria monocytogenes from retail foods. Int. J. Food Microbiol. 190:24-30.

Yang L, Huang B, Hu W, Chen Y, Mao M, Yao L, 2014. The impact of greenhouse vegetable farming duration and soil types on phytoavailability of heavy metals and their health risk in eastern China. Chemosphere 103:121-130.

Zubero MB, Aurrekoetxea JJ, Ibarluzea JM, Arenaza MJ, Rodríguez C, Sáenz JR, 2010. Heavy metal levels ( Pb, Cd, Cr and $\mathrm{Hg}$ ) in the adult general population near an urban solid waste incinerator. Sci. Total Environ. 408:4468-4474. 